\title{
Research Article: Study the type of advice given and constraints experienced in running the agricultural input centers
}

\section{Y.J. WAGHMODE, A.N. DESAI AND RADHIKA BHONGALE}

Article Chronicle: Received :

24.07.2015;

Revised :

26.07.2015;

Accepted :

25.08.2015

\section{KEY Words:}

Advice given,

Constraints

experienced, Input

dealers
SUMMARY : Agriclinics are envisaged to provide expert services and advice to farmers on cropping practices, technology dissemination, crop protection from pest and diseases, market trends and prices of various crops in the markets and also clinical services for animal health etc., which would enhance productivity of crops and animals. Therefore, the present study was conducted to study the type of advice given and constraints experienced in running the agricultural input centres by the agricultural input dealers. The research study was carried out in 9 tahsils of Ratnagiri district in Konkan region of Maharashtra State during 2011-2012. Result of this study revealed that that two-third (65.33\%) of the respondents from region had 'fair' advisory service about their role in transfer of farm technology while 18.67 per cent of the respondents had 'good' advisory service about their role in transfer of farm technology. Further 16.00 per cent of the respondents had 'poor' advisory service about their role in transfer of farm technology. Similarly in case of constraints majority $(97.33 \%)$ of the agricultural input dealers faced the problem of 'availability of labour', followed by 'lack of organization of dealers $(81.33$ $\%)$ 'delay in effecting payment by farmers towards the purchase' (77.33\%), 'transportation' $(74.67 \%)$ and availability of agricultural input.

How to cite this article : Waghmode, Y.J., Desai, A.N. and Bhongale, Radhika (2015). Study the type of advice given and constraints experienced in running the agricultural input centers. Agric. Update, 10(3): 262-265.

Author for correspondence :

\section{Y.J. WAGHMODE}

Department of

Extension Education,

College of Agriculture,

Dr. Balasaheb Sawant

Konkan Krishi

Vidyapeeth, Dapoli,

RATNAGIRI (M.S.) INDIA

Email: waghmodeyogesh

@gmail.com

See end of the article for

authors' affiliations 